\title{
ELIZABETH A. McHARG
}

Elizabeth Adam McHarg was born on 22nd April, 1923 and died on 29th April, 1999. She was a daughter of a schoolmaster, born in Coatbridge and educated at the Glasgow High School for Girls and at the universities of Glasgow and Cambridge. At the end of a distinguished undergraduate career in Glasgow in 1943, she graduated MA with First Class Honours in Mathematics and Natural Philosophy and was awarded along with Adeline O. M. Cook, a classicist, the Thomas Logan Medal and Prize for the most distinguished graduate in Arts of the year. She was also awarded a George A. Clark scholarship which enabled her to go to Girton College, Cambridge, as a research student. She studied under Miss (later Dame Mary) Cartwright who at that time was intensely interested in non-linear differential equations and, in particular, in the one associated with the eminent Dutch physicist van der Pol. Betty, as she was known to her friends, worked in this field and, in due course, obtained her PhD.

In 1948 Betty returned to Glasgow and thereafter, as a lecturer and later as a senior lecturer in mathematics, rendered devoted service to the university for almost 40 years. After she returned to Glasgow she lost interest in non-linear differential equations - not the easiest subject on which to do research - and devoted the bulk of her effort to teaching and reading widely in mathematics. She had tremendous technical skill in the manipulation of heavy algebra and was an expert on the Special Functions of mathematical physics. It has often been said that had she been born a decade or so earlier and so had been ready to commence research just when quantum mechanics was beginning to be applied to chemistry and extensive use was being made of these functions, she would have come into her own and might well have become very distinguished indeed.

Betty had a great appreciation of beauty in mathematics, especially in geometry, the almost complete removal of which from the school syllabus she deeply regretted. When she took her turn as an examiner for the Entrance Bursary Examination, she set some beautiful, but perhaps too difficult, questions on geometry.

Teaching being a prime consideration for Betty, she lectured with consummate skill in the best tradition of Scottish university lecturing. Her lectures were models of clarity and good arrangement. As a colleague she was conscientious, reliable, a stickler for accuracy, and forth-right in expressing her opinions, whether they were pleasing to hear or otherwise. Betty's interests were not confined to mathematics. She was widely cultured and, possessing considerable linguistic skills, she translated into English a standard work on differential equations by the Italian mathematician Tricomi.

Betty was powerful physically as well as intellectually. On one occasion something like 40 years ago she, along with a young lady from the university office, walked from Blair Atholl up Glen Tilt and over to the Pools of Dec, a distance of about 25 miles, on a Saturday, climbed Lochnagar on the Sunday, and walked from Braemar through the Lairig Ghru to Aviemore, 27 miles away, on the Monday. Her physical strength showed itself also on the tennis court. Tennis being almost an obsession with her at times, she played it until her illness eventually forbade her.

Betty will be remembered with gratitude by thousands of former students for the clarity of her exposition and for her great command of excellent English. She will also be remembered with affection as a faithful and generous friend and as a unique 
personality by the steadily diminishing number of her former colleagues and contemporaries.

Dan Martin

(REPRODUCED BY KIND PERMISSION OF THE HERALD, GLASGOW)

\section{PUBLICATIONS}

A differential equation, J. London Math. Soc. 22 (1947), 83-85.

F. G. Tricomi, Differential equations, Translated by Elizabeth A. McHarg (Hafner Publishing Co., New York, 1961). 